\title{
Pengaruh Brand Loyalty dan Perceived Quality terhadap Kepuasan Pembelian
}

\author{
Mohammad Wasil \\ Fakultas Ekonomi dan Bisnis Universitas Mulawarman, Samarinda \\ E-mail: wasield@gmail.com
}

\begin{abstract}
Abstrak
Brand Loyalty dan Perceived Quality terhadap Kepuasan Pembelian Ponsel Galaxy Berbasis Android Samsung. Penelitian ini bertujuan untuk mengetahui dan menganalisis pengaruh Brand Loyalty dan Perceived Quality terhadap Kepuasan Pembelian Handset Galaxy Berbasis Samsung Galaxy dan untuk mengetahui mana dari dua variabel Brand Loyalty dan Perceived Quality yang memiliki pengaruh paling dominan terhadap kepuasan pembelian ponsel Samsung Galaxy Berbasis Android oleh mahasiswa Fakultas Ekonomi Universitas Mulawarman, Samarinda. Teori yang mendasari penelitian ini adalah Manajemen Pemasaran dengan menggunakan regresi linier berganda. Berdasarkan hasil analisis dan pembahasan, dapat disimpulkan dalam penelitian ini bahwa: $\mathrm{Y}=6,224+0,141 \mathrm{X} 1+0,377$ $\mathrm{X} 2$. Hasil analisis menunjukkan bahwa ada pengaruh signifikan antara Brand Loyalty dan Perceived Quality terhadap kepuasan pembelian handphone Samsung Galaxy Berbasis Android dan pengaruh paling dominan pada kepuasan pembelian handphone Samsung Galaxy Berbasis Android oleh para mahasiswa Fakultas Ekonomi, Universitas Mulawarman, Samarinda adalah Variabel Kualitas yang Diterima. Hipotesis pertama yang diajukan oleh peneliti diterima dan terbukti secara statistik, sedangkan hipotesis kedua tidak diterima dan secara statistik belum terbukti.
\end{abstract}

Kata Kunci: Brand Loyalty, Perceived Quality, Consumer Gratification, Teori Statoff Tradeoff

\section{The Influence of Brand Loyalty and Perceived Quality on Purchasing Satisfaction}

\begin{abstract}
Brand Loyalty and Perceived Quality toward the Satisfaction of Purchasing Samsung's Android-Based Galaxy Handphones. This research aims to find out and to analyze the influence of Brand Loyalty and Perceived Quality toward the Satisfaction of Purchasing Samsung's Android-Based Galaxy Handphones and to find out which one from the two variables of Brand Loyalty and Perceived Quality has the most dominant influence on the satisfaction of purchasing Samsung's Android-Based Galaxy handphones by the students of Faculty of Economy, Mulawarman University, Samarinda. The theory underlying this research is Marketing Management by using Multiple Linear regression. Based on the result og analysis and discussion, it can be concluded in this research that: $\mathrm{Y}=6,224+0,141 \mathrm{X}_{1}+0,377 \mathrm{X}_{2}$. The result of analysis revealed that there was simultaneous significant of influence of Brand Loyalty and Perceived Quality on the satisfaction of purchasing Samsung's Android-Based Galaxy handphones and the most dominant influence on the satisfaction of purchasing Samsung's Android-Based Galaxy handphone by the students of Faculty of Economy, Mulawarman University, Samarinda was Perceived Quality Variable. The first hypothesis that was proposed by the researcher was accepted and statistically proven, while the second hypothesis was not accepted and statistically unproven.
\end{abstract}

Keywords: Brand Loyalty, Perceived Quality, Consumer Gratification, Static Tradeoff Theory 


\section{PENDAHULUAN}

Sejalan dengan perkembangan zaman yang begitu cepat serta kemajuan teknologi disegala bidang di dunia, peralatan elektronik mendominasi kegiatan manusia saat ini, seperti komputer, telephone dan berbagai peralatan modern lainnya menjadikan segala aktifitas dan kegiatan manusia menjadi lebih mudah dan cepat. Manusia sebagai makhluk sosial tentunya tidak bisa lepas dari hubungan dengan individu lainnya. Hal ini mendorong manusia untuk dapat memenuhi kebutuhan berkomunikasi dalam kehidupan sosialnya.

Mengingat dunia modern saat ini dimana mobilitas yang tinggi menyebabkan manusia yang terdiri dari berbagai lapisan masyarakat menginginkan alat komunikasi yang cepat terakses dan dapat mendukung segala aktivitasnya. Handphone (telepon genggam) menjadi salah satu alat komunikasi yang mampu menjawab keinginan dan kebutuhan tersebut.

Pasar handphone mengalami perkembangan yang cukup pesat, hal ini dapat dilihat dengan semakin banyaknya bermunculan berbagai merek handphone yang menawarkan berbagai macam model serta teknologi canggih dengan bentuk dan fasilitas tambahan yang lengkap khususnya dalam mengakses sistem jejaring sosial yang sedang menjadi trend dikalangan masyarakat.

Samsung Galaxy yang berbasis Android dipandang sebagai alat komunikasi berkualitas. Daya tahan perangkat, nilai jual kembali, tersedianya beragam produk sesuai peruntukan, fitur yang menarik, sistem operasi perangkat yang canggih, serta pengoperasian alat yang mudah menjadi keunggulan tersendiri yang memenuhi kepuasan mahasiswa dalam membeli handphone Samsung Galaxy yang berbasis Android.

Handphone Samsung Galaxy berbasis Android yang beredar dipasaran saat ini setidaknya ada 13 tipe yaitu, Samsung Galaxy Spica I5700, Samsung Galaxy S, Samsung Galaxy Gio, Samsung Galaxy Pro, Samsung Galaxy Ace, Samsung Galaxy Mini, Samsung Galaxy Young, Samsung Galaxy Wonder, Samsung Galaxy S II, Samsung Galaxy Poket, Samsung Galaxy Nexus dan Samsung Glaxy Fit $S$ 5670. (sumber: www.google.com)

Menurut Zeithmal dan Bitner, (2003) yang meneliti tentang pengaruh kualitas pelayanan terhadap kepuasan dan loyalitas pelanggan, meningkatnya persepsi kualitas pelayanan akan menyebabkan pelanggan tersebut loyal. Hal ini selaras dengan dua kategori yang menjadi bagian dari konsep ekuitas merek berupa Brand Loyalty (loyalitas merek) sebagai suatu ukuran keterkaitan pelanggan kepada sebuah merek, dimana hal ini dapat terjadi dengan melakukan pembelian serta mempunyai pengalaman menggunakan dan juga Perceived Quality (kesan kualitas) yang merupakan persepsi terhadap keseluruhan kualitas/keunggulan suatu produk atau jasa, dimana sebuah merek memberikan alasan yang penting untuk membeli, mempengaruhi merek-merek mana yang mesti dipertimbangkan dan pada gilirannya mempengaruhi merek apa yang bakal dipilih.

\section{TINJAUAN PUSTAKA}

\section{Pengertian Manajemen Pemasaran}

Pemasaran merupakan fungsi yang penting bagi perusahaan, dimana dalam memasarkan produknya, produsen harus pandai membaca situasi pasar sekarang dan masa yang akan datang. Arti bagian pemasaran harus cepat tanggap memahami apa yang diinginkan dan dibutuhkan oleh konsumen, kemudian kapan dan dimana dibutuhkannya. salah satu tujuan kegiatan pemasaran adalah upaya untuk mempengaruhi konsumen atau calon konsumen agar bersedia membeli produk yang dihasilkan oleh perusahaan.

Menurut Stanton dalam Swastha dan Handoko (2008:4) yaitu:

"Pemasaran adalah suatu sistem keseluruhan dari kegiatan-kegiatan usaha yang ditujukan untuk merencanakan, menentukan harga, mempromosikan dan mendistribusikan barang dan jasa yang dapat memuaskan kebutuhan baik kepada pembeli yang ada maupun pembeli potensial".

Sedangkan definisi pemasaran menurut Kotler (2005:10):

"Pemasaran adalah proses sosial dengan proses satu individu dan kelompok mendapatkan apa yang mereka butuhkan dan inginkan dengan menciptakan, menawarkan, dan secara bebas mempertukarkan produk dan jasa yang bernilai dengan pihak lain".

Selanjutnya The American Marketing Assosiations (2004) memberikan pengertian pemasaran sebagai berikut: 
"Marketing is an organizational function and a set of processes for creating, communicating and delivering value to customer relationships in way that benefit the organizational and it's stakeholders".

Artinya Pemasaran adalah suatu fungsi organisasi dan satu perangkat dari proses untuk menciptakan, berkomunikasi dan menawarkan sebuah nilai atau harga kepada pelanggan dan untuk mengatur hubungan pelanggan dengan cara untuk mendapatkan keuntungan bagi organisasi dan pemilik atau pemegang saham.

Dengan beberapa pengertian diatas, jelaslah bahwa kegiatan pemasaran bukan semata-mata kegiatan yang mengaktualisasi pertukaran potensial saja, tetapi sampai pada pemuasan kebutuhan dan keinginan konsumen. Dalam hal ini maka kepuasan konsumen merupakan tolak ukur keberhasilan bisnis sebuah perusahaan.

Manajemen Pemasaran adalah mengadministrasikan fungsi-fungsi pemasaran yang menyangkut perencanaan, penganalisaan, dan pengawasan program yang telah direncanakan untuk menciptakan, menumbuhkan dan mempertahankan pertukaran saling menguntungkan sehingga mencapai target dan tujuan perusahaan. Sedangkan fungsi terakhir dari manajemen pemasaran adalah pengawasan yang dilakukan untuk menghindari adanya penyimpangan yang mungkin terjadi.

Pengertian Manajemen Pemasaran menurut Assauri (2009:12) adalah :

"Manajemen pemasaran merupakan kegiatan penganalisisan, perencanaan, pelaksanaan, dan pengendalian program-program yang dibuat untuk membentuk, membangun, dan memelihara keuntungan dari pertukaran melalui sasaran pasar guna mencapai tujuan organisasi (perusahaan) dalam jangka panjang".

Dalam pengertian lainnya yang dikemukakan oleh Kotler dan Keller (2006:6), manajemen pemasaran adalah:

"Marketing management as the art and science of choosing target markets and getting, keeping, and growing customers through creating, delivering, and communicating superior customer value".

Artinya manajemen pemasaran sebagai seni dan ilmu dari pemilihan target pasar dan mendapatkan, menjaga, serta menambah pelanggan melalui produksi, distribusi dan komunikasi yang memberi nilai lebih bagi konsumen.

Kegiatan pemasaran dalam suatu perusahaan harus diorganisasikan secara terpadu serta memerlukan suatu pelaksanaan manajemen pemasaran yang berorientasi pada kepuasan pelanggan dan kesejahteraan lingkungan untuk mendukung kegiatan pemasaran, perlu diperhatikan suatu konsep yang disebut konsep pemasaran.

Menurut Assauri (2007:81) Konsep Pemasaran adalah suatu falsafah manajemen dalam bidang pemasaran yang berorientasi kepada kebutuhan dan keinginan konsumen dengan didukung oleh kegiatan pemasaran terpadu yang diarahkan untuk memberikan kepuasan konsumen sebagai kunci keberhasilan organisasi dalam usahanya mencapai tujuan yang telah ditetapkan.

Sedangkan Konsep Pemasaran atau The Market Concept, menurut Kotler (2006:16)

"The holds that key to achieving its organizational goals consists of the company being more effective than competitors in creating, delivering, and communicating customer value to its chosen target markets".

Dari pendapat diatas dapat diartikan yaitu konsep pemasaran menegaskan bahwa kunci untuk mencapai tujuan organisasi yang ditetapkan adalah perusahaan tersebut harus manjadi efektif dibandingkan para pesaing dalam menciptakan, menyerahkan dan mengkomunikasikan kepada pasar sasaran yang terpilih.

Menurut Kotler (2003:20-25) ada lima konsep pemasaran yang mendasari cara organisasi melakukan kegiatan pemasaran, yaitu:

\section{Konsep produksi}

Konsep ini berpendapat bahwa konsumen akan memilih produk yang mudah didapat dan murah harganya. Manajemen organisasi yang berwawasan produksi memusatkan perhatiannya untuk mencapai efisiensi produksi yang tinggi serta mencakup distribusi yang luas. 


\section{Konsep Produk}

Konsep ini berpendapat bahwa konsumen akan memilih produk yang menawarkan mutu, kinerja yang baik atau hal-hal yang inovatif lainnya. Manajer dalam konsep ini memutuskan perhatiannya untuk membuat produk yang lebih baik dan terus menyempurnakannya.

\section{Konsep Penjualan}

Konsep ini berpendapat bahwa konsumen dibiarkan saja, konsumen tidak akan membeli produk organisasi dalam jumlah cukup. Manajer organisasi harus melaksanakan usaha penjualan dan promosi yang agresif.

\section{Konsep Pemasaran}

Konsep ini berpendapat kunci untuk mencapai tujuan organisasi adalah terdiri dari penentuan kebutuhan dan keinginan pasar sasaran serta memberikan kepuasan yang diinginkan secara lebih efektif daripada saingannya.

\section{Konsep Pemasaran bermasyarakat}

Konsep ini beranggapan bahwa tugas perusahaan adalah menentukan kebutuhan, keinginan serta kepentingan pasar sasaran dan memenuhinya dengan lebih efektif serta lebih efisien dari pada saingannya dengan cara mempertahankan atau meningkatkan kesejahteraan konsumen dan masyarakat.

Secara definitif dapat dikatakan bahwa konsep pemasaran adalah falsafah bisnis yang menyatakan bahwa pemuasan kebutuhan konsumen merupakan syarat ekonomi dan sosial bagi kelangsungan hidup perusahaan. Swastha dan Handoko (2008:6).

Dari uraian tersebut di atas dapat disimpulkan bahwa konsep ini menyatakan bahwa tugas perusahaan tidak hanya menetapkan sasaran dan memberi kepuasan yang diinginkan konsumen secara efektif dan efisien, tetapi juga dapat menjaga dan meningkatkan kesejahteraan konsumen dan masyarakat.

\section{Pengertian Produk}

Produk yang dipasarkan hendaknya produk yang sesuai dengan kebutuhan dan keinginan konsumen sehingga dengan demikian maka konsumen akan merasa puas, hanya dengan kepuasan konsumen itulah perusahaan akan mendapatkan keuntungan. Sebaliknya apabila konsumen tidak merasa puas terhadap produk yang dibelinya maka mereka akan meninggalkan produk itu dan perusahaan tersebut akan kehilanggan pelanggan serta akhirnya akan menderita kerugian.

Menurut Winardi (2004:316) definisi produk adalah segala sesuatu baik yang disukai maupun yang tidak disukai yang diterima seseorang dalam sebuah perusahaan. yaitu:

Sedangkan menurut Kotler (2003:38) menyatakan bahwa produk dibagi menjadi dua kategori,

a. Produk konsumen adalah produk yang dibeli untuk memuaskan kebutuhan pribadi dan kebutuhan keluarga.

b. Produk Industri adalah produk yang dibeli untuk dipergunakan dalam operasi perusahaan atau untuk membuat produk lain.

Produk merupakan apa saja yang ditawarkan kepasar untuk memenuhi keinginan dan kebutuhan. Produk juga merupakan elemen kunci dalam penawaran pasar.

Menurut Kotler dan Amstrong dalam (Rahman, 2010:9) produk adalah:

"segala sesuatu yang ditawarkan ke pasar untuk mendapatkan perhatian, dibeli, dipergunakan, dan yang dapat memuaskan keinginan atau kebutuhan konsumen".

Selain itu berdasarkan siapa konsumennya dan untuk apa produk tersebut dikonsumsi, menurut Tjiptono (2008:98) produk dapat dibedakan menjadi:

Barang konsumen (consumer's goods) adalah barang yang dikonsumsi untuk kepentingan konsumen akhir sendiri (individu dan rumah tangga), bukan untuk tujuan bisnis. Umumnya barang konsumen dapat diklasifikasikan dalam empat jenis yaitu: 
a) Convenience Good, merupakan barang yang pada umumnya memiliki frekuensi pembelian tinggi (sering dibeli), dibutuhkan dalam waktu segera, dan hanya memerlukan usaha yang minimum (sangat kecil) dalam pembandingannya dan pembeliannya.

b) Shopping Goods, merupakan barang-barang yang dalam proses pemilihan dan pembeliannya dibandingkan oleh konsumen di antara berbagai alternatif yang tersedia.

c) Specialty Goods, merupakan barang-barang yang memiliki karakteristik dan/atau identifikasi merek yang unik dimana sekelompok konsumen bersedia melakukan usaha khusus untuk membelinya.

d) Unshought Goods, merupakan barang-barang yang tidak diketahui konsumen atau kalaupun sudah diketahui, tetapi paa umumnya belum terpikirkan untuk membelinya.

Barang industri (industrial's goods) adalah barang-barang yang dikonsumsi oleh industriawan (konsumen antara atau konsumen bisnis) untuk keperluan selain dikonsumsi langsung. Barang industri diklasifikasikan dalam tiga kelompok barang industri yaitu:

a) Materials and Parts, merupakan barang-barang yang seluruhnya atau sepenuhnya masuk ke dalam produk jadi.

b) Capital Item, merupakan barang-barang tahan lama (long-lasting) yang memberi kemudahan dalam mengembangkan dan/atau mengelola produk jadi.

c) Supplies and Services, merupakan barang-barang tidak tahan lama (short-lasting) dan jasa yang memberi kemudahan dalam mengembangkan dan/atau mengelola keseluruhan produk jadi.

\section{Pengertian Merek}

Merek adalah alat efektif untuk mempertahankan dan meningkatkan penjualan. Jika merek telah memberikan kepuasan kepada konsumen, maka konsumen tersebut akan kembali mencari dan membeli merek tersebut, karena selalu diingat oleh konsumen.

Menurut Susanto dan Wijanarko (2004:7) pengertian merek:

"Merek adalah nama atau symbol yang diasosiasikan dengan produk atau jasa dan menimbulkan arti psikologis atau asosiasi”. berikut:

Sedangkan menurut Kotler dan Keller (2006:256) merek mempunyai pengertian sebagai

"Brand as a name, term, sign, symbol, or design, or a combination of them, intended to identify the goods or services of one seller or group of seller and to differentiate them from those of competitos".

Artinya merek adalah nama, istilah, tanda, simbol, rancangan atau kombinasi dari hal-hal tersebut, yang dimaksudkan untuk mengidentifikasi barang atau jasa dari seseorang atau sekelompok penjual dan untuk membedakannya dari pesaing".

Ekuitas merek yang tinggi dapat memberikan berbagai keunggulan bersaing bagi perusahaan. Merek yang kuat akan menumbuhkan kesadaran akan merek dan loyalitas konsumen yang tinggi, karena konsumen ingin memilih merek tertentu pada saat berbelanja. Perusahaan pemilik merek tertentu tersebut juga mempunyai kekuatan tawar-menawar yang lebih tinggi dengan pedagang perantara, karena nama merek tersebut mempunyai kredibilitas yang besar, perusahaan yang bersangkutan lebih mudah meluncurkan perluasan produk dan merek.

Menurut Kartajaya (2004:196) definisi ekuitas merek adalah asset intangible yang dimiliki oleh sebuah merek karena value yang diberikannya, baik kepada si produsen maupun si pelanggan.

Sedangkan menurut Kotler (2003:350) ekuitas merek adalah nilai suatu merek berdasarkan seberapa kuat merek tersebut mempunyai loyalitas merek, kesadaran konsumen akan nama merek, kualitas yang dipersepsikan, asosiasi merek dan berbagai asset lainnya seperti paten, merek dagang dan hubungan jaringan distribusi.

Dapat disimpulkan bahwa ekuitas merek adalah seperangkat aset yang berkaitan dengan suatu merek yang memberi nilai tambah bagi perusahaan maupun konsumennya.

Berikut adalah gambar Ekuitas Merek: 


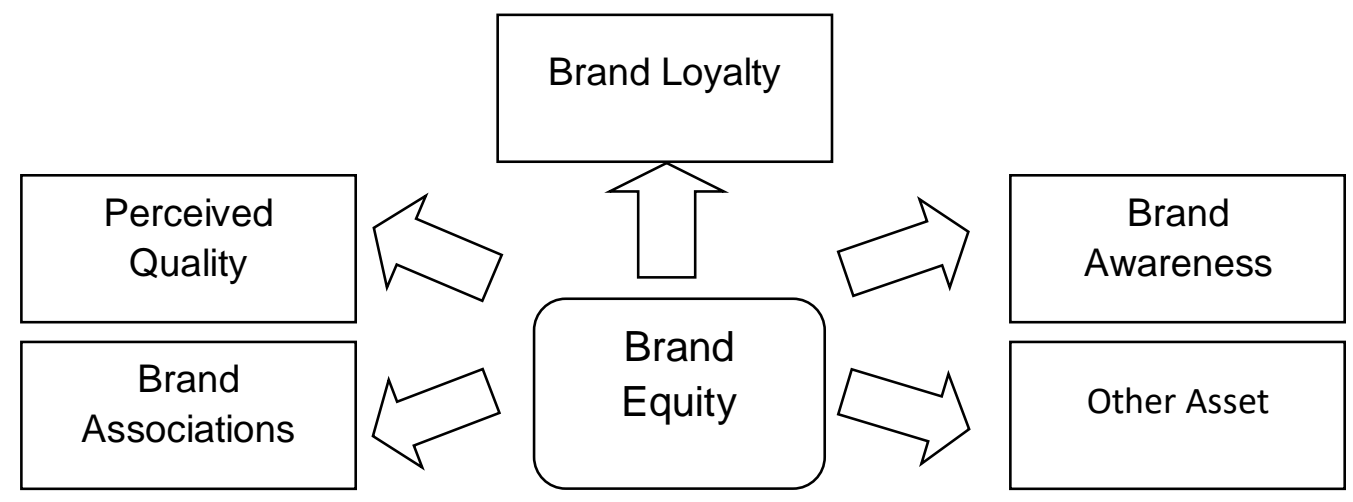

Gambar 2.1. Atribut Ekuitas Merek menurut Kotler dan Keller dalam (Handayani, 2010:62)

Dari gambar di atas dapat dilihat bahwa ekuitas merek terdiri dari 5 atribut yaitu:

\section{Brand Loyalty (Loyalitas Merek)}

Loyalitas merek adalah ukuran dari kesetiaan konsumen terhadap suatu merek. Loyalitas merek merupakan inti dari Brand Equity yang menjadi gagasan sentral dalam pemasaran, karena hal ini merupakan suatu ukuran keterkaitan seseorang pelanggan pada sebuah merek. Apabila loyalitas merek meningkat maka kerentaan kelompok pelanggan dari serangan kompetitor dapat dikurangi. Hal ini merupakan suatu indikator dari Brand Equity yang berkaitan dengan perolehan laba dimasa yang akan datang karena loyalitas merek secara langsung dapat diartikan sebagai penjualan di masa depan.

\section{Brand Awareness (Kesadaran Merek)}

Aaker (Handayani, 2010:64) mendefinisikan brand awareness sebagai kemampuan dari seorang pelanggan potensial untuk mengenali atau mengingat kembali bahwa suatu merek merupakan bagian dari kategori atau produk tertentu. Bagian dari suatu kategori produk perlu ditekankan karena terdapat suatu hubungan yang kuat antara kategori produk dengan merek yang dilibatkan.

Kemampuan pelanggan untuk mengenali atau mengingat suatu merek produk tergantung pada tingkat komunikasi atau persepsi pelanggan terhadap merek produk yang ditawarkan. Berikut adalah tingkatan dari brand awareness (Handayani, 2010:64):

a) Unware of brand

Pada tahapan ini, pelanggan merasa ragu atau tidak yakin apakah sudah mengenali merek yang disebutkan atau belum.

b) Brand recognition

Pada tahapan ini, pelanggan mampu mengenditifikasi merek yang disebutkan.

c) Brand recall

Pada tahapan ini, pelanggan mampu mengingat merek tanpa diberikan stimulus.

d) Top of mind

Pada tahapan ini, pelanggan mengingat merek sebagai yang pertama kali muncul di pikiran saat berbicara mengenai kategori produk tertentu.

\section{Perceived Quality (Kesan Kualitas)}

Pengertian kesan kualitas menurut A.Aaker (Rangkuti, 2004:41) adalah persepsi pelanggan terhadap keselurhan kualitas atau keunggulan suatu produk atau jasa layanan berkaitan dengan maksud yang diharapkan.

\section{Brand Association (Asosiasi Merek)}

Aaker dalam Managing Brand Equity (Handayani, 2010:66) mendefinisikan brand association sebagai "Segala sesuatu yang terhubung di memori pelanggan terhadap suatu merek". Asosiasi merek merupakan kesan yang muncul di benak konsumen yang terkait dengan ingatan mengenai suatu merek 
(Durianto, 2004:69). Kesan tersebut akan semakin meningkat seiring dengan semakin banyaknya pengalaman konsumen dalam mengkonsumsi suatu merek. Merek yang memiliki kesan kuat di benak konsumen akan memengaruhi konsumen dalam menentukan pilihan dalam pembelian.

Di sisi lain menurut Keller dalam (Chasanah, 2003:106) bahwa asosiasi merek didorong pula oleh identitas dari merek tersebut yang ingin dibangun oleh perusahan. Lebih lanjut disebutkan oleh keller, asosiasi merek memiliki berbagi tipe sebagai berikut :

a) Atributes (Atribut), asosiasi yang dikaitkan terhadap atribut-atribut dari merek tersebut, baik yang berhubungan langsung terhadap produknya maupun yang tidak berhubungan langsung terhadap produknya. Seperti harga (price), perasaan (feeling), pengalaman (experiences) dan personalitas merek (brand Personality).

b) Benefit (manfaat) asosiasi suatu merek dikaitkan dengan manfaat fungsional (fungsional Benefit), manfaat simbolik (symbolic benefit), dari pemakaian dan pengalaman yang dirasakan oleh pengguna (experiental Benefit).

c) Attitudes (Sikap), asosiasi yang muncul dikarenakan motivasi diri sendiri yang merupan sikap dari berbagi sumber, seperti Punishment, Reward dan Ilmu pengetahuan (Knowledge). patents, trade mark, dan lain sebagainya.

\section{Other Asset (Aset Lainnya)}

Aset-aset lainnya yang dimaksud di sini adalah seperti keunggulan bersaing, paten, merek dagang, dan hubungan dengan channel.

\section{(LoyalitBrand Loyaltyas Merek)}

Menurut Durianto (2004:126) brand loyalty merupakan ukuran kedekatan pelanggan pada sebuah merek. Konsumen yang loyal pada umumnya akan melanjutkan penggunaan merek tersebut walaupun dihadapkan dengan banyak alternatif merek produk pesaing yang menawarkan karakteristik produk yang lebih unggul.

Loyalitas memiliki tingkatan sebagaimana dapat dilihat pada diagram berikut ini :

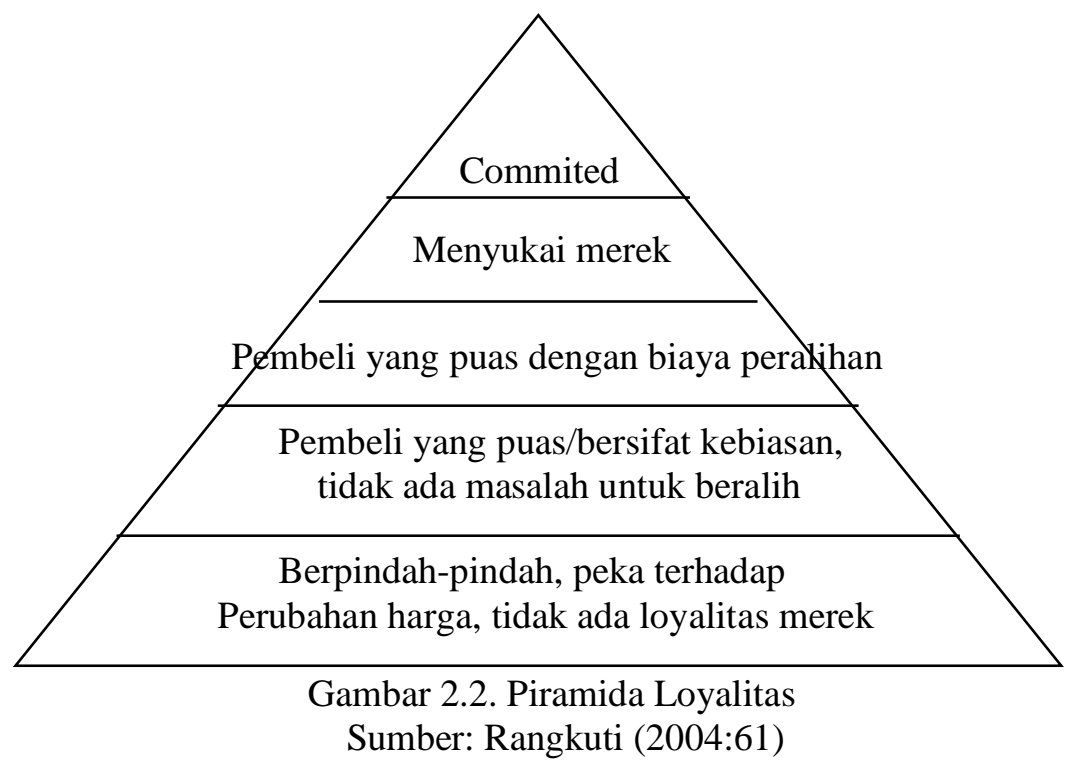

Berdasarkan piramida di atas, maka bisa dijelaskan yaitu:

a) Tingkat loyalitas yang paling dasar adalah pembeli tidak loyal atau samasekali tidak tertarik pada merek-merek apapun yang ditawarkan. Dengan demikian, merek memainakan peran yang kecil dalam keputusan pembelian. Pada umumnya konsumen seperti ini suka berpindah-pindah merek atau disebut tipe konsumen Switcher atau price buyer (konsumen yang lebih memperhatikan harga di dalam melakukan pembelian). 
b) Tingkat kedua adalah para pembeli merasa puas dengan produk yang digunakan, atau minimal tidak mengalami kekecewaan. Pada dasarnya, tidak terdapat dimensi ketidak puasan yang dapat menjadikan sumber perubahan, apalagi apabila perpindahan ke merek yang lain itu ada penambahan biaya. Para pembeli tipe ini dapat disebut pembeli tipe kebiasaan (habitual buyer).

c) Tingkat ketiga berisi orang-orang yang puas, tapi harus memikul biaya peralihan (Switching Cost), baik dalam waktu, uang atau resiko sehubungan dengan upaya untuk melakukan pergantian ke merek lain. Kelompok ini biasanya disebut dengan konsumen loyal yang merasakan adanya suatu pengorbanan apabila ia melakukan penggantian ke merek lain. Para pembeli tipe ini disebut satisfied buyer.

d) Tingkat keempat adalah konsumen benar-benar menyukai merek tersebut. Pilihan mereka terhadap suatu merek dilandasi pada suatu asosiasi, seperti simbol, rangkaian pengalaman, atau kesan kualitas yang tinggi. Para pembeli pada tingkat ini di sebut sahabat merek, karena terdapat perasan emosional dalam menyukai merek.

e) Tingkat teratas adalah para pelanggan yang setia. Mereka mempunyai suatu kebanggan dalam menemukan atau menjadi pengguna satu merek. Merek tersebut menjadi penting bagi mereka baik dari segi fungsinya, maupun sebagai ekspresi mengenai siapa mereka sebenarnya (commited buyer).

f) Dari piramida loyalitas diatas terlihat bahwa bagi merek yang belum memiliki brand equity yang kuat, porsi tersebut dari konsumennya berada pada tingkatan switcher hingga porsi terkecil, di tempati oleh commited buyer. Meskipun demikian bagi merek yang memiliki brand equity yang kuat, tingkatan dalam brand loyalty-nya diharapkan membentuk segitiga terbalik, maksudnya makin ke atas makin melebar sehingga diperoleh jumlah commited buyer yang lebih besar dari pada switcher tampak pada gambar berikut:

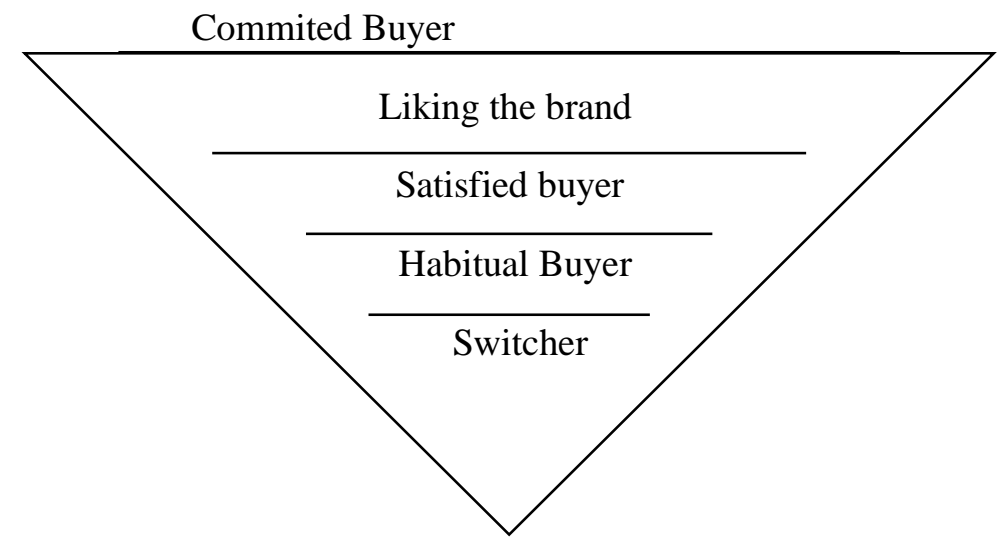

Gambar 2.3. Piramida 2 Brand Loyalty

Sumber: Durianto, Sugiarto, Sitinjak (Adam, 2003:23)

\section{Perceived Quality (Persepsi Kualitas)}

Persepsi kualitas mencerminkan perasaan pelanggan yang tidak nampak dan secara menyeluruh mengenai suatu merek. Akan tetapi, biasanya persepsi kualitas didasarkan pada dimensi-dimensi yang termasuk dalam karakteristik produk tersebut dimana merek dikaitkan dengan hal-hal seperti keandalan dan kinerja. Kesan kualitas memberikan nilai dalam beberapa bentuk seperti dapat dilihat pada diagram berikut ini: 


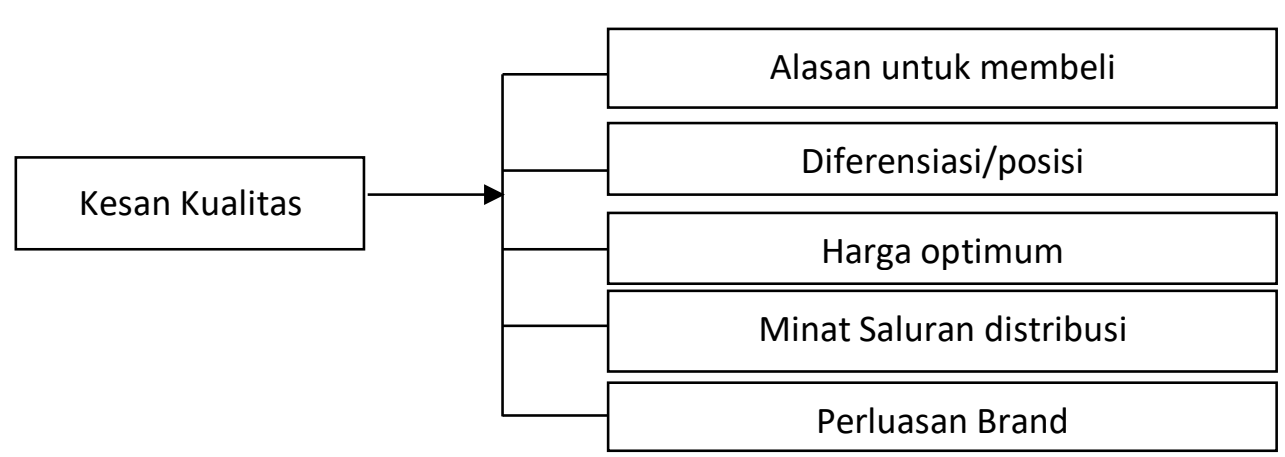

Gambar 2.4. Gambar Diagram Nilai dari Kesan Kualitas Sumber : Rangkuti, (2004:42)

Terdapat lima keuntungan kesan kualitas, yaitu:

\section{Alasan membeli}

Kesan kualitas sebuah merek memberikan alasan yang penting untuk membeli. Hal ini mempengaruhi merek-merek mana yang harus dipertimbangkan, dan selanjutnya mempengaruhi merek apa yang akan dipilih.

\section{Diferensiasi/posisi}

Diferensiasi mempunyai arti merupakan suatu karakteristik penting dari merek untuk memposisikannya dalam dimensi kesan kualitas.

\section{Harga optimum}

Keuntungan ini memberikan pilihan-pilihan didalam menetapkan harga optimum.

\section{Minat Saluran distribusi}

Keuntungan ini yaitu meningkatkan minat para distributor dikarenakan adanya suatu arti penting bagi para distributor, pengecer serta berbagai saluran distribusi lainya sehingga kejadian ini akan membantu perusahaan dalam perluasan distribusi.

\section{Perluasan Brand}

Kesan kualitas dapat dieksploitasi dengan cara mengenalkan berbagai perluasan merek, yaitu dengan menggunakan merek tertentu untuk masuk kedalam kategori produk baru.

\section{Kepuasan Konsumen}

Sambandam dan Lord (1995) meneliti mengenai kepuasan konsumen yang menunjukkan adanya pengaruh positif antara pengalaman pembelian sebelumnya terhadap tingkat kepuasan. Dengan adanya pengalaman terhadap pembelian sebelumnya kemungkinan hanya sedikit ketidaksesuaian antara harapan dan kinerja serta kemungkinan kecil terhadap ketidakpuasan. Berdasarkan pengalaman yang diperolehnya, pelanggan memiliki kecenderungan untuk membangun nilai-nilai ekspektasi tertentu. Nilai ekspektasi tersebut akan memberikan dampak bagi pelanggan untuk melakukan perbandingan terhadap kompetitor dari produk yang pernah dirasakannya. Secara langsung penilaian tersebut akan mempengaruhi pandangan dan penilaian pelanggan terhadap perusahaan kompetitor.

Berdasarkan hal-hal tersebut maka variabel kepuasan pelanggan dapat dibentuk dari tiga indikator, yaitu kesesuaian harapan, persepsi kinerja, dan penilaian pelanggan. 
Indikator-indikator Kepuasan Pelanggan

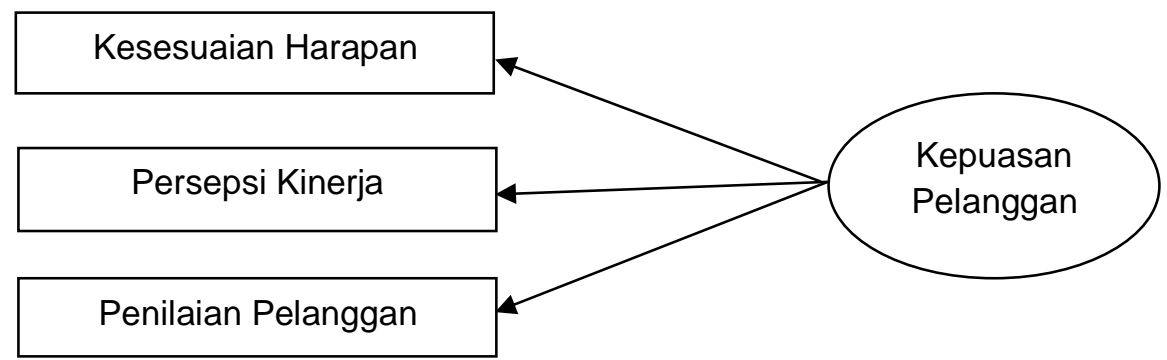

Gambar 2.5. Indikator Kepuasan Pelanggan

Sumber: Spreng, Mackenzie \& Olshavsky (1996) dikembangkan dalam penelitian ini (www.google.com)

\section{Hubungan dan Pengaruh Brand Loyalty Terhadap Kepuasan Konsumen}

Di era persaingan yang semakin ketat ini, salah satu cara untuk mendapatkan konsumen yang loyal adalah dengan memuaskan kebutuhan konsumen secara konsisten dari waktu ke waktu. Banyak cara yang dapat digunakan perusahaan untuk memuaskan kebutuhan konsumen (Erna Ferrinadewi, 2005).

Kepuasan konsumen merupakan sikap, penilaian dan respon emotional yang ditunjukkan oleh konsumen setelah proses pembelian/konsumsi yang berasal dari perbandingan kesannya terhadap kinerja aktual terhadap suatu produk dan harapannya dan evaluasi terhadap pengalaman mengkonsumsi suatu produk atau jasa (Wilkie, 1994).

Loyalitas merek merupakan preferensi konsumen secara konsisten untuk melakukan pembelian pada merek yang sama pada produk yang spesifik atau kategori pelayanan tertentu (Schiffman dan Kanuk, 2004).

Oliver dalam Tjiptono( 2005:387) mengemukakan bahwa :

Loyalitas merek adalah komitmen yang dipegang teguh untuk membeli ulang atau berlangganan dengan produk atau jasa yang disukai secara konsisten di masa mendatang, sehingga menimbulkan pembelian merek yang sama secara berulang meskipun pengaruh situasional dan upaya pemasaran berpotensi menyebabkan perilaku beralih merek.

\section{Hubungan dan pengaruh Perceived Quality Terhadap Kepuasan Konsumen}

Menurut Tjiptono (2005), persepsi kualitas adalah penilaian konsumen terhadap keunggulan atau superioritas produk secara keseluruhan. Oleh karena itu kesan kualitas didasarkan evaluasi subyektif konsumen terhadap kualitas konsumen.

Persepsi kualitas yang tinggi menunjukkan bahwa konsumen telah menemukan perbedaan dan kelebihan produk tersebut dengan produk sejenis setelah melalui jangka waktu yang lama. Zeithaml dalam Harianto (2006) menyatakan bahwa persepsi kualitas adalah komponen dari nilai merek oleh karena itu persepsi kualitas yang tinggi akan mendorong konsumen untuk lebih memilih merek tersebut dibandingkan dengan merek pesaing Persepsi kualitas adalah salah satu kunci dimensi ekuitas merek.

Sedangkan menurut Kotler (2000: 36) kepuasan adalah perasaan seseorang mengenai kesenangan atau kecewa dari hasil perbandingan kinerja produk atau layanan yang diterima dengan harapan. Apakah pelanggan puas setelah pembelian tergantung pada kinerja tawaran sehubungan dengan harapan pelanggan. Kepuasan merupakan fungsi dari persepsi atau kesan atas kinerja dan harapan. Harapan dari pelanggan dipengaruhi oleh pengalaman pembelian mereka sebelumnya, nasihat teman dan kolega, dan janji ataupun informasi pemasar dan para pesaingnya.

\section{Kerangka Konsep dan Model Penelitian}

Berdasarkan judul yaitu “ Analisis Pengaruh Brand Loyalty dan Perceived Quality Terhadap Kepuasan Pembelian Handphone Samsung Galaxy Berbasis Android". Maka variabel yang menjadi dasar konsepsional dalam penelitian ini adalah: 
a) Brand Loyalty (Loyalitas Merek) adalah suatu ukuran keterkaitan pelanggan kepada sebuah merek.

b) Perceived Quality (Kesan Kualitas) adalah persepsi pelanggan terhadap keseluruhan kualitas atau keunggulan suatu produk atau jasa layanan berkenaan dengan maksud yang diharapkan.

c) Kepuasan Pembelian adalah perasaan puas yang dirasakan oleh pelanggan karena mendapatkan sesuatu yang diinginkan.

Berdasarkan latar belakang permasalahan, berikut ini dikemukakan kerangka konsep penelitian dimana dari kedua variabel bebas terdapat satu variabel yaitu Perceived Quality $\left(\mathrm{X}_{2}\right)$ merupakan variabel yang dikendalikan, (sugiyono, 2010: 237):

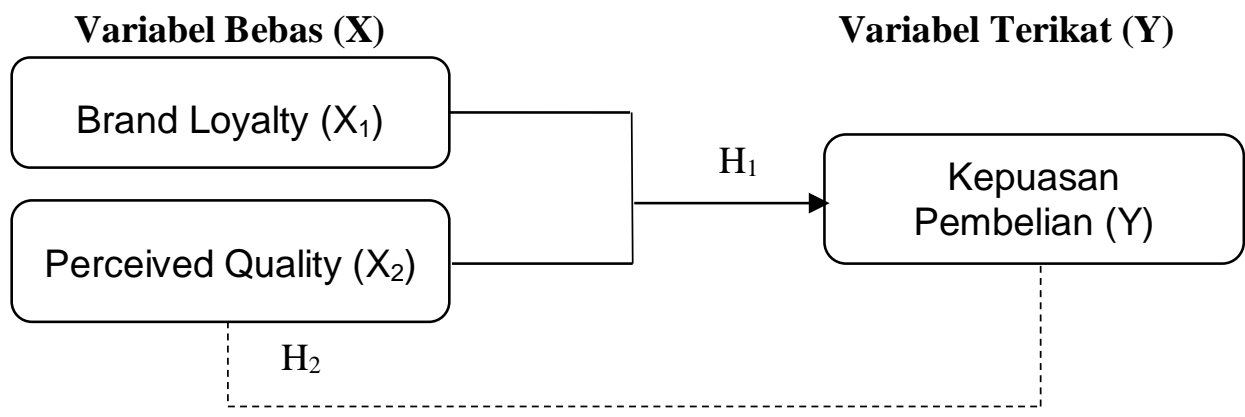

Gambar 2.6. Kerangka Konsep

\section{Pengembangan Hipotesis}

Menurut Zeithmal dan Bitner, (2003) yang meneliti tentang pengaruh kualitas pelayanan terhadap kepuasan dan loyalitas pelanggan, meningkatnya persepsi kualitas pelayanan akan menyebabkan pelanggan tersebut loyal. Dan dalam penelitian ini peneliti menggunakan dua variabel tersebut yaitu Brand Loyalty dan Perceived Quality terhadap Kepuasan Pembelian. Brand Loyalty adalah ukuran dari kesetiaan konsumen terhadap suatu merek. Ukuran ini mampu memberikan gambaran tentang mungkin tidaknya seorang pelanggan beralih ke merek lain, terutama jika merek tersebut didapati adanya perubahan, baik menyangkut harga ataupun atribut yang lain. Seorang pelanggan yang sangat loyal kepada suatu merek tidak akan dengan mudah memindahkan pembelian ke merek yang lain, apapun yang terjadi dengan merek tersebut. Perceived Quality adalah persepsi pelanggan terhadap keseluruhan kualitas atau keunggulan sesuatu menyeluruh mengenai suatu merek. Untuk memahami Perceived Quality suatu merek diperlukan pengukuran suatu dimensi yang terkait dengan karakteristik produk.

Sebagaimana telah dibahas diatas, maka penulis menarik hipotesis sebagai berikut :

$\mathrm{H}_{1}$ : Diduga bahwa terdapat pengaruh antara Variabel Brand Loyalty dan Variabel Perceived Quality terhadap Kepuasan Pembelian Handphone Samsung Galaxy pada Mahasiswa Fakultas Ekonomi Universitas Mulawarman Samarinda.

$\mathrm{H}_{2}$ : Diduga yang berpengaruh dominan terhadap kepuasan pembelian handphone Samsung Galaxy Berbasis Android adalah Variabel Perceived Quality pada Mahasiswa Fakultas Ekonomi Universitas Mulawarman.

\section{METODE PENELITIAN}

\section{Populasi}

Populasi adalah wilayah dan generalisasi yang terdiri atas: obyek/subyek yang mempunyai kualitas dan karakteristik tertentu yang ditetapkan oleh peneliti untuk dipelajari dan kemudian ditarik kesimpulan (Sugiyono, 2010: 80). Dalam penelitian ini mengambil populasi Mahasiswa jenjang studi S1 Fakultas Ekonomi Universitas Mulawarman kelas pagi (Reguler) sebanyak 2.025 mahasiswa.

\section{Sampel}

Sampel (sample) adalah sebagian dari populasi. Sampel terdiri atas sejumlah anggota yanbg dipilih dari populasi. Dengan kata lain, sejumlah, tapi tidak semua, elemen populasi akan membentuk 
sampel. Jadi, sampel adalah subkelompok atau sebagian dari populasi. Dengan mempelajari Sampel, peneliti akan mampu menarik kesimpulan yang dapat digeneralisasikan terhadap populasi penelitian (Uma Sekaran, 2006: 123).

Teknik pengumpulan sampel yang digunakan adalah Sampling Insidental dimana teknik penentuan sampel berdasarkan kebetulan, yaitu siapa saja yang secara kebetulan bertemu dengan peneliti dapat digunakan sebagai sampel, bila dipandang orang yang kebetulan ditemui cocok sebagai sumber data (Sugiyono, 2010:85). Dan pengumpulan sampel ini dilakukan dalam waktu 2 bulan.

\section{Definisi Operasional dan Pengukuran Variabel}

Untuk menjelaskan penelitian tentang tulisan ini maka perlu diberikan batasan-batasan definisi operasional sebagai berikut:

\section{Brand Loyalty $\left(\mathrm{X}_{1}\right)$}

Brand Loyalty adalah suatu ukuran keterkaitan pelanggan kepada merek Samsung Galaxy Berbasis Android. Dengan indikatornya adalah:

a) Kesetian (kebanggaan) pelanggan terhadap penggunaan handphone Samsung Galaxy.

b) Menyukai merek (rangkaian pengalaman) handphone Samsung Galaxy.

c) Membutuhkan pengorbanan (waktu yang lama dan biaya lebih besar) apabila beralih dari handphone Samsung Galaxy.

d) Peralihan kepada merek lain, jika handphone samsung galaxy memberikan resiko/kerugian.

e) Pembeli suka berpindah-pindah merek karena mempertimbangkan harga di dalam melakukan pembelian.

\section{Perceived Quality $\left(\mathbf{X}_{2}\right)$}

Perceived Quality adalah persepsi pelanggan terhadap keseluruhan kualitas atau keunggulan produk handphone Samsung Galaxy Berbasis Android berkenaan dengan maksud yang diharapkan. Indikatornya berupa:

a) Kesan kualitas sebuah merek memberikan alasan yang penting untuk membeli Samsung Galaxy.

b) Samsung Galaxy mempunyai karakteristik penting dari merek untuk memposisikannya dalam dimensi kesan kualitas.

c) Samsung Galaxy memberikan pilihan-pilihan didalam menetapkan harga optimum.

d) Keuntungan yang diperoleh Handphone Samsung Galaxy akan membantu perusahaan dalam perluasan distribusi.

e) Handphone Samsung Galaxy mengenalkan berbagai perluasan merek, yaitu dengan menggunakan merek tertentu untuk masuk kedalam kategori produk baru.

\section{Kepuasan Pembelian (Y)}

Kepuasan Pembelian adalah perasaan puas yang dirasakan oleh konsumen terhadap pembelian handphone merek handphone Samsung Galaxy Berbasis Android. Indikatornya adalah:

1) Kesesuaian Harapan konsumen terhadap kualitas handphone Samsung Galaxy.

2) Persepsi Kinerja dari keseluruhan aplikasi yang dimiliki handphone Samsung Galaxy

\section{Metode Pengumpulan Data}

Dalam usaha untuk memperoleh dan mendapatkan data yang diperlukan dan dianggap penting dalam rangka penulisan ini teknik pengumpulannya adalah dengan melakukan wawancara langsung kepada Mahasiswa Fakultas Ekonomi Universitas Mulawarman, Observasi dengan mengamati langsung terhadap obyek yang diteliti, Angket dengan memberikan kuisioner kepada Mahasiswa Fakultas Ekonomi Universitas Mulawarman, khususnya pengguna handphone Samsung Galaxy dan dengan melakukan Penelitian Kepustakaan yaitu dengan mengadakan riset yang berhubungan dengan konsep untuk mendukung konsep keilmiahan, yang dalam hal ini diperoleh dari literatur yang berhubungan dengan permasalahan yang akan dibahas. 


\section{HASIL DAN PEMBHASAN}

\section{Analisis Data \\ Pengujian Hipotesis \\ Pengujian Validitas}

Simamora (2004:172) menyatakan bahwa validitas adalah suatu ukuran yang menunjukkan tingkat kevalidan atau keaslihan suatu instrumen. Suatu instrumen dianggap valid apabila mampu mengukur apa yang diinginkan. Dengan kata lain, mampu memperoleh data yang tepat dari variabel yang diteliti.

Menurut Ghozali (2006:45) uji validitas digunakan untuk mengukur sah atau valid tidaknya suatu kuesioner. Suatu kuesioner dikatakan valid jika pertanyaan pada kuesioner mampu untuk mengungkapkan sesuatu yang akan diukur oleh kuesioner tersebut.

Penelitian memerlukan data yang betul valid dan reliabel. Dalam rangka urgensi ini, maka kuesioner sebelum digunakan sebagai data penelitian primer, terlebih dahulu diujicobakan ke sampel uji coba penelitian. Uji coba ini dilakukan untuk memperoleh bukti sejauh mana ketepatan dan kecermatan alat ukur dalam melakukan fungsi ukurnya

\section{Pengujian Reliabilitas}

Menurut Simamora (2004:177) reliabilitas adalah tingkat keandalan kuisioner. Kuisioner yang reliable adalah kuisioner yang apabila dicobakan secara berulang-ulang kepada kelompok yang sama akan menghasilkan data yang sama

Menurut Ghozali (2006:41) reliabilitas adalah alat untuk mengukur suatu kuesioner yang merupakan indikator dari variabel atau konstruk. Suatu kuesioner dikatakan reliabel atau handal jika jawaban seseorang terhadap pernyataan adalah konsisten atau stabil dari waktu ke waktu. Asumsinya, tidak terdapat perubahan psikologis pada responden. Apabila data yang diperoleh sesuai dengan kenyataannya, berapakalipun pengambilan data dilakukan, hasilnya tetap sama.

\section{Analisis Regresi Linier Berganda}

Alat analisis yang digunakan penulis dalam penelitian ini adalah regresi linier berganda. Simamora (2004:339) Regresi linier berganda adalah suatu teknis analisis yang digunakan untuk mengetahui hubungan antara variabel bebas (independen) dengan variabel tidak bebas (dependen). Di dalam penelitian ini yang menjadi variabel bebas adalah Brand Loyalty dan Perceived Quality. Sedangkan variabel tidak bebasnya adalah kepuasan konsumen terhadap pembelian handphone merk samsung galaxy.

Untuk memperoleh data, penulis melakukan pengukuran dengan menggunakan Skala Likert (Sugiyono, 2010: 93). Dengan bobot pemberian nilai sebagai berikut:

1. Jawaban "a" diberi skor 5

2. Jawaban "b" diberi skor 4

3. Jawaban "c" diberi skor 3

4. Jawaban "d" diberi skor 2

5. Jawaban "e" diberi skor 1

Untuk menguji dan membuktikan kebenaran hipotesis menggunakan alat analisis Regresi Berganda dengan alat bantu menggunakan program SPSS. Bentuk persamaan yang digunakan (Sugiyono, 2010:275) adalah sebagai berikut:

$$
\begin{array}{ll}
\mathrm{Y}=\mathrm{a}+\mathrm{b}_{1} \mathrm{X}_{1}+\mathrm{b}_{2} \mathrm{X}_{2} \\
\text { dimana: } & \\
\mathrm{Y} & =\text { Variabel dependent (Kepuasan Pembelian) } \\
\mathrm{a} & =\text { Konstanta } \\
\mathrm{b}_{1}, \mathrm{~b}_{2} & =\text { Koefisien Regresi } \\
\mathrm{X}_{1}, \mathrm{X}_{2} & =\text { Variabel independent } \mathrm{X}_{1} \text { (Brand Loyalty), } \mathrm{X}_{2} \text { (Perceived Quality) }
\end{array}
$$

\section{Pembahasan}


Berdasarkan data yang telah disajikan sebelumnya dengan menggunakan alat-alat analisis yaitu regresi linier berganda, analisis korelasi berganda, uji hipotesis dengan menggunakan uji f (serentak) dan uji t (parsial) dengan menggunakan program bantu SPSS seri 17.0, maka dapat dikemukakan hasil analisis koefisien regresi berganda dengan persamaan:

$$
\mathrm{Y}=6,224+0,141 \mathrm{X}_{1}+0,377 \mathrm{X}_{2}
$$

Berdasarkan persamaan tersebut, dapat dijelaskan bahwa variabel Brand Loyalty dan Perceived Quality mempunyai pengaruh positif terhadap kepuasan (Y) konsumen terhadap pembelian handphone Samsung Galaxy berbasis Android, yang artinya bila variabel Brand Loyalty dan Perceived Quality ditingkatkan maka akan meningkatkan kepuasan pembelian konsumen.

Nilai R sebesar 0,485 menggambarkan hubungan antara variabel bebas terhadap variabel terikat. Jika melihat pada tabel interprestasi koefisien korelasi (Sugiyono, 2006: 216), dinyatakan dari interval 0,40 sampai dengan 0,599 memiliki hubungan yang sedang. Karena nilai 0,485 berada pada interval tersebut artinya terdapat keeratan hubungan yang sedang antara variabel bebas (brand loyalty dan perceived quality) terhadap variabel terikat (kepuasan pembelian). Dan nilai R Square sebesar 0,236, menunjukan bahwa kedua variabel bebas memberikan pengaruh sebesar 23,6\% terhadap kepuasan pembelian konsumen dan selebihnya sebesar $76,4 \%$ dipengaruhi oleh variabel lain yang tidak dikemukakan dalam model penelitian ini.

Nilai uji $F_{\text {hitung }}$ sebesar 14,951dengan tingkat signifikansi sebesar $0,000<0,05(\alpha=5 \%$ atau tingkat kepercayaan sebesar $95 \%$ ), bila dibandingkan dengan $F_{\text {tabel }}$ sebesar 3,96, maka $F_{\text {hitung }}>F_{\text {tabel }}$, dengan demikian hipotesisnya Ho ditolak dan Ha diterima, hal ini berarti brand loyalty dan perceived quality secara bersama-sama berpengaruh signifikan terhadap kepuasan pembelian handphone Samsung Galaxy.

Pengujian secara parsial dilakukan dengan cara membandingkan $t_{\text {hitung }}$ dengan $t_{\text {tabel }}$ dengan $\alpha=$ $0,05(5 \%)$ atau tingkat kepercayaan sebesar $95 \%$, diketahui bahwa nilai $t_{\text {tabel }}$ sebesar 1,9847. Apabila nilai $t_{\text {hitung }}>t_{\text {tabel }}$, maka Ho ditolak dan Ha diterima atau signifikan berarti secara parsial ada hubungan yang berarti antara brand loyalty $\left(\mathrm{X}_{1}\right)$ dan perceived quality $\left(\mathrm{X}_{2}\right)$ terhadap kepuasan pembelian $(\mathrm{Y})$ handphone Samsung Galaxy atau hipotesis yang diajukan dapat diterima. Sebaliknya apabila $t_{\text {hitung }}<$ $t_{\text {tabel }}$ maka Ho diterima dan Ha ditolak atau tidak signifikan berarti secara parsial tidak terdapat hubungan yang berarti antara brand loyalty $\left(\mathrm{X}_{1}\right)$ dan perceived quality $\left(\mathrm{X}_{2}\right)$ terhadap kepuasan pembelian (Y) handphone Samsung Galaxy atau hipotesis yang diajukan dapat ditolak.

Hasil perhitungan untuk variabel brand loyalty diperoleh nilai uji $t_{\text {hitung }}>t_{\text {tabel }}$ atau 2,741 $>2,390$. Dalam hal ini dengan membandingkan antara $t_{\text {hitung }}$ dan $t_{\text {tabel }}$ dari variabel brand loyalty $\left(\mathrm{X}_{1}\right)$ tersebut, dapat diketahui bahwa hasil perhitungan ini menunjukan hubungan yang signifikan secara parsial antara variabel brand loyalty $\left(\mathrm{X}_{1}\right)$ dan variabel kepuasan pembelian $(\mathrm{Y})$ sehingga hipotesisnya adalah HO ditolak dan menerima Ha.

Hasil perhitungan untuk variabel perceived quality diperoleh nilai uji $t_{\text {hitung }}>t_{\text {tabel }}$ atau 3,736 $>2,390$, Dalam hal ini dengan membandingkan antara $t_{\text {hitung }}$ dan $t_{\text {tabel }}$ dari variabel perceived quality $\left(\mathrm{X}_{2}\right)$ tersebut, dapat diketahui bahwa hasil perhitungan ini menunjukan hubungan yang signifikan secara parsial antara variabel perceived quality $\left(\mathrm{X}_{2}\right)$ dan variabel kepuasan pembelian $(\mathrm{Y})$ sehingga hipotesisnya adalah $\mathrm{HO}$ ditolak dan menerima Ha.

Dengan demikian dari kedua variabel yaitu brand loyalty $\left(\mathrm{X}_{1}\right)$ dan perceived quality $\left(\mathrm{X}_{2}\right)$ secara parsial keduanya memiliki hubungan yang signifikan terhadap variabel kepuasan pembelian (Y). Berdasarkan perhitungan tersebut di atas, variabel perceived quality $\left(\mathrm{X}_{2}\right)$ diketahui berpengaruh dominan terhadap kepuasan pembelian (Y) handphone Samsung Galaxy, hal ini dibuktikan dengan diperoleh $t_{\text {hitung }}>t_{\text {tabel }}$ atau 3,736 $>2,390$ dan didukung dengan tingkat signifikansi sebesar 0,000<0,05. Oleh karena itu hipotesis kedua yang menyatakan diduga variabel perceived quality $\left(\mathrm{X}_{2}\right)$ yang berpengaruh dominan terhadap kepuasan pembelian handphone Samsung Galaxy adalah diterima.

\section{SIMPULAN}

Berdasarkan hasil penelitian, analisis dan pembahasan yang telah dilakukan mengenai kepuasan pembelian Handphone Samsung Galaxy Berbasis Android oleh Mahasiswa Jenjang studi S1 Reguler 
Fakultas Ekonomi Universitas Mulawarman Samarinda, maka dapat ditarik kesimpulan sebagai berikut:

1. Dari hasil analisis regresi linier berganda diperoleh persamaan, dimana dari persamaan tersebut dapat diketahui bahwa variabel brand loyalty $\left(\mathrm{X}_{1}\right)$ dan perceived quality $\left(\mathrm{X}_{2}\right)$ secara bersama-sama mempunyai pengaruh yang positif terhadap kepuasan pembelian $(\mathrm{Y})$ dalam pembelian handphone Samsung Galaxy, yang artinya bila variabel brand loyalty dan perceived quality ditingkatkan maka akan semakin meningkatnya kepuasan pembelian.

2. Dari nilai $\mathrm{R}$ yang diperoleh melalui perhitungan dapat disimpulkan keseluruhan variabel bebas yaitu variabel brand loyalty $\left(\mathrm{X}_{1}\right)$ dan perceived quality $\left(\mathrm{X}_{2}\right)$ memilki hubungan yang sedang terhadap variabel kepuasan pembelian (Y).

3. Setelah dilakukan Uji $\mathrm{F}$ didapatkan nilai uji $\mathrm{F}_{\text {hitung }}>\mathrm{F}_{\text {tabel }}$ maka dapat disimpulkan bahwa Ho ditolak dan Ha diterima, hal ini berarti brand loyalty dan perceived quality secara bersama-sama berpengaruh signifikan terhadap kepuasan pembelian handphone Samsung Galaxy.

4. Berdasarkan Uji t atau uji parsial, maka dapat diketahui bahwa variabel yang dominan adalah variabel perceived quality dengan membandingkan nilai $t_{\text {hitung }}$ dan $t_{\text {tabel }}$, nilai uji $t_{\text {hitung }}>t_{\text {tabel }}$ dengan demikian $\mathrm{H}_{1}$ diterima dan $\mathrm{H}_{2}$ ditolak, sehingga dapat disimpulkan bahwa perceived quality memiliki pengaruh dominan dibandingkan dengan variabel lainnya.

\section{SARAN}

Berdasarkan hasil penelitian dan kesimpulan yang diambil, maka dapat disarankan beberapa hal sebagai berikut:

1. Bagi perusahaan hendaknya memperhatikan bagian dari ekuitas merek yakni perceived quality karena mempunyai pengaruh yang signifikan terhadap kepuasan konsumen handphone Samsung Galaxy.

2. Nilai variabel perceived quality yang berpengaruh dominan perlu menjadi perhatian serius pihak perusahaan, kesan kualitas yang baik terhadap produk handphone Samsung Galaxy menjadi sangat penting sebagai faktor yang mempengaruhi tingkat kepuasan konsumen terhadap pembelian produk handphone Samsung Galaxy.

3. Bagi para peneliti yang berminat untuk mengkaji dan meneliti ulang penelitian ini, disarankan lebih memperdalam dan memperluas variabel penelitian, indikator penelitian, memperluas wilayah kajian penelitian serta memperdalam kerangka teoritis. Hal ini dikarenakan perhitungan yang menunjukan bahwa masih banyaknya variabel lain yang belum diteliti sehingga memberikan peluang yang besar bagi peneliti lain untuk mengembangkan lebih lanjut.

\section{DAFTAR PUSTAKA}

Assauri, Sofjan. 2009. Manajemen Pemasaran Dasar, Konsep dan Strategi, Raja Grafindo Persada. Jakarta.

Alma, Buchari. 2011. Manajemen Pemasaran dan Pemasaran Jasa, Alfabeta. Bandung.

http://feedproxy.google.com/ r/JournalOfKnowledge/ 3/Z6tmLL_txfo/, di akses pada tanggal 23 April 2012.

http://www.kusukagadget.com/features/sejarah-versi-android, di akses pada tanggal 19 April 2012

http://library.gunadarma.ac.id/repository/view/18445/analisis-pengaruh-ekuitas merek-, di akses pada tanggal 18 April 2012.

http://www.unmul.ac.id/index.php?option=com_content\&view=article\&id=95\&Itemid=73, di akses pada tanggal 19 April 2012.

Kotler, Philip. 2005. Manajemen Pemasaran, (Marketing Management), alih bahasa Drs. Benyamin Malon, Edisi Bahasa Indonesia Jilid 1. Erlangga. Jakarta.

Kotler, Philip dan Keller, Kevin L. 2006. Marketing Management, Pearson International Edistion. Printice Hall. Englewood. New Jersey.

Kotler, Philip 2009. Manajemen Pemasaran, Edisi 13, Erlangga. Jakarta. 
Rahman. 2010. Strategi Dahsyat Marketing Mix for Small Busines, Trans Media Pustaka. Jagakarsa. Rangkuti, Freddy. 2007. Riset Pemasaran, Gramedia Pustaka Utama. Jakarta.

Schiffman Leon dan Kanuk, Lazar Leslie. 2004. Consumer Behavior. International Edition. Printice Hall. Englewood. New Jersey.

Sekaran, Uma. 2006. Metodologi Penelitian untuk Bisnis, Edisi 4, Salemba Empat. Jakarta

Simamora, Bilson. 2004. Riset Pemasaran Falsafah, Teori, dan Aplikasi. PT Gramedia Pustaka Utama. Jakarta.

Sugiyono. 2010. Metode Penelitian Kuantitatif Kualitas dan R\&D, Cetakan Kesembilan. Alfabeta, cv. Bandung.

Sugiyono. 2010. Statistika Untuk Penelitian, Alfabeta. Bandung.

Sumarwan, dkk. 2011. Riset Pemasaran Dan Konsumen. PT Penerbit IPB Press. Bogor.

Sunarto. 2006. Perilaku Konsumen. AMUS. YOGYAKARTA.

Swastha, Basu dan T. Hani Handoko. 2008, Manajemen Pemasaran Analisis Perilaku Konsumen, Edisi Pertama, BPFE UGM. Yogyakarta.

Tjiptono, Fandi. 2008, Strategi Pemasaran, Edisi III. ANDI. Yogyakarta.

Umar, Husein. 2010. Riset Pemasaran \& Perilaku Konsumen, PT Gramedia Pustaka Utama. Jakarta. www.google.com, diunduh pada tanggal 3 November 2012. www.samsung.com, diunduh pada tanggal 31 Oktober 2012. 